
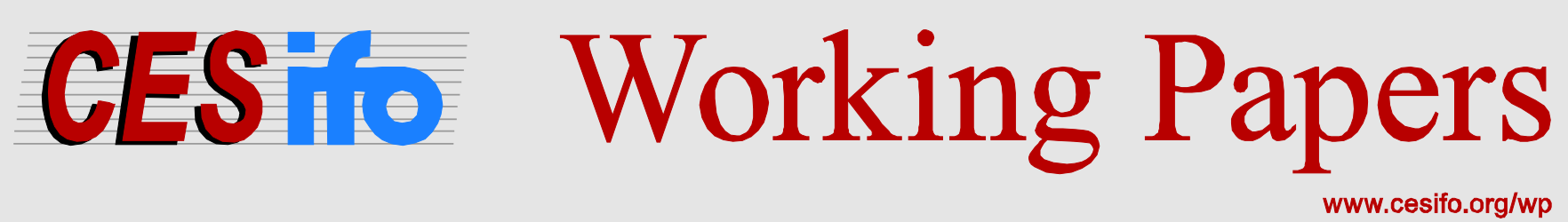

\title{
Did Globalization Influence Credit Market Deregulation?
}

\author{
Peter Eppinger \\ Niklas Potrafke
}
CESIFO WORKING PAPER NO. 5374
CATEgory 2: Public CHOICE
MAY 2015

An electronic version of the paper may be downloaded

- from the SSRN website:

- from the RePEc website:

- from the CESifo website:

wWw.SSRN.com

Www.RePEc.org

www.CESifo-group.org/wp

\section{CESifo}




\title{
Did Globalization Influence Credit Market Deregulation?
}

\begin{abstract}
We investigate whether globalization influenced credit market deregulation over the period 1970-2010. Globalization is measured by the KOF indices of globalization. Credit market deregulation is measured by the credit market freedom indicators of the Fraser Institute. The results from both cross-sectional and panel regressions using ordinary least squares indicate a positive correlation between globalization and credit market deregulation. We account for reverse causality by using predicted trade openness as an instrumental variable and show that this approach gives rise to different conclusions. Two-stage least squares estimations do not show that globalization had a causal influence on credit market deregulation.
\end{abstract}

JEL-Code: F650, F680, G180, G280, F420, C260.

Keywords: globalization, credit market deregulation, instrumental variables.

Peter Eppinger

University of Tübingen

International Economics Department

Mohlstrasse 36

Germany-72074 Tübingen

peter.eppinger@uni-tuebingen.de
Niklas Potrafke*

Ifo Institute - Leibniz Institute for

Economic Research

at the University of Munich

Poschingerstrasse 5

Germany - 81679 Munich

potrafke@ifo.de

*corresponding author

20 May 2015

This paper has been accepted for publication in The World Economy.

We thank Peter Egger, Gabriel Felbermayr, Jasmin Gröschl, Richard Kneller, and Heinrich Ursprung for helpful suggestions to improve the paper. We are grateful to Gabriel Felbermayr and Jasmin Gröschl for providing their data and codes. Fabio Duchi provided excellent research assistance. 


\section{Introduction}

An intriguing issue is how globalization influences financial markets, especially credit market deregulation. Sinn (2010) maintains, for example, that lax credit market regulation gave rise to the global financial crisis starting in 2007 (competition in laxity). The systems competition theory predicts that globalization triggers competition between national governments to reduce size and scope of government (race-to-the-bottom hypothesis). A smaller size and scope of government in the course of globalization encompasses, for example, lower tax rates and public expenditures, lower product standards, and less pronounced employment protection (e.g., Sinn, 1997). ${ }^{1}$ Sinn's (2003) The New Systems Competition - Chapter 7: Limited Liability, Risk-Taking and the Competition of Bank Regulators describes how globalization gives rise to credit market deregulation. ${ }^{2}$ Sinn's model shows that banks' equity requirements are lax when national banks compete for international lenders. When governments impose strict equity requirements on banks, international lenders are likely to deal with banks in other countries in which equity requirements are less strict. Consequently: “the bank lobbies' pressure on national governments not to impose stricter banking rules than do competing countries is therefore overwhelming, and in fact the pressure goes in the direction of national liberalization" (Sinn, 2003: 209).

Scholars have used the KOF index of globalization to investigate empirically how globalization influenced financial markets. Globalization has increased national preferences for market financing as measured by the domestic stock market capitalization relative to domestic assets of deposit money banks. Aggarwal and Goodell (2009: 1778) interpret this result "as suggesting that societal openness is generally associated more with the development

\footnotetext{
${ }^{1}$ On the globalization-welfare state nexus see, for example, Schulze and Ursprung (1999), Ursprung (2008), Dreher et al. (2008a), and Meinhard and Potrafke (2012). On globalization and social justice see Kauder and Potrafke (2015).

2 "While the national regulation decisions were normally designed in periods where the banks' lenders were predominantly nationals, globalization has changed the situation substantially. International banking competition has become fierce, possible acquisitions by competitors have become a constant threat to banking managers, and cheap international refinancing has become the cue for banking success in all countries" (Sinn, 2003: 191).
} 
of markets than with the development of banking". Globalization increased international risk sharing. Pierucci and Ventura (2012: 1) conclude that "economic and social integration help to better cope with idiosyncratic risk, but also that without political integration this might result in an increasing exposure to (uninsurable) risk." Economic globalization increased the probability of banking crises (Klomp, 2010). In East Asian countries, globalization has been shown to influence financial development as measured by private-sector credit granted by the banking sector and the stock capitalization of the equity markets. ${ }^{3}$ Granger causality test results show that globalization influenced institutional quality, which, in turn, promoted financial development. Globalization directly influenced stock markets (Law et al., 2014 and 2015).

Our study is most closely related to Heinemann and Tanz (2008) who investigate how social trust influences economic reforms. Their study includes one regression using the first difference of the overall credit market deregulation indicator by the Frazer Institute as dependent variable. Heinemann and Tanz (2008) estimate a cross-sectional OLS model including 54 countries and use the KOF index of globalization as a control variable. The results show that globalization was somewhat negatively correlated with the first difference of the overall credit market deregulation indicator between 1995 and 2005, indicating that globalization induced credit market regulation. The studies by Aggarwal and Goodell (2009), Pierucci and Ventura (2012), Klomp (2010) and Heinemann and Tanz (2008) do however not deal with reverse causality. Causality between globalization and credit market deregulation may be reverse: it is conceivable that deregulated credit markets, for example, attract foreign investment.

We provide new empirical evidence on whether globalization has induced credit market deregulation over the period 1970-2010. Descriptive analysis indicates a positive

\footnotetext{
${ }^{3}$ By improving institutions, such as strong property rights, globalization is expected to promote financial development (Mishkin, 2009).
} 
correlation between globalization and credit market deregulation in a large sample of countries. This correlation is confirmed in both cross-sectional and panel regressions using ordinary least squares (OLS). We account for reverse causality by using predicted trade openness as an instrumental variable (IV) and show that this approach gives rise to different conclusions. First, we use the geographic component of trade openness (Frankel and Romer, 1999) as an IV in the long-run cross-section. Second, we combine geography with natural disasters in third countries to predict trade openness in the panel, as suggested by Felbermayr and Gröschl (2013). Two-stage least squares (2SLS) estimations do not show that globalization had a causal influence on credit market deregulation.

We describe the data and some descriptive statistics in Section 2. Section 3 describes the empirical strategy. Section 4 shows the results of the cross-sectional and panel data estimations. Section 5 concludes.

\section{Data}

\subsection{Credit market deregulation}

To measure credit market deregulation, we use the index on credit market freedom of the Economic Freedom of the World (EFW) index by the Fraser Institute (Gwartney et al., 2012). This index consists of three sub-indicators that measure deregulation regarding the ownership of banks, private sector credit, and interest rate controls or negative real interest rates. The ownership of banks sub-indicator is based on the "percentage of bank deposits held in privately owned banks". Credit market deregulation is higher, the larger is the share of privately held deposits. The private sector credit sub-indicator "measures the extent to which government borrowing crowds out private borrowing". Credit market deregulation is higher, the higher is the share of credit extended to the private sector. The interest rate control subindicator measures whether real interest rates were determined by the market or by the 
government and whether real deposit and lending rates were positive or negative. Credit market deregulation is higher, when real interest rates are determined by the market and when real deposit and lending rates are positive. Table A1 shows the detailed description of the three sub-indicators as provided by Gwartney et al. (2012). The indicators are normalized to range from 0 to 10 , with higher scores representing higher economic freedom and less regulation. The aggregate index is calculated as the arithmetic mean of the ratings of its three sub-indicators.

The dataset by Gwartney et al. (2012) is an unbalanced panel. For the year 2010, the overall credit market regulation index is available for 142 countries. Data are initially available in five year intervals for the years 1970, 1975, 1980, 1985, 1990, 1995 and 2000. Annual data are available for the period 2001-2010.

\subsection{The 2012 KOF index of globalization}

The 2012 KOF index of globalization cumulates 23 variables to an overall index and three sub-indices covering the economic, social, and political dimensions of globalization (see Dreher, 2006, and Dreher et al., 2008b). ${ }^{4}$ The economic globalization index includes two groups of variables: (i) actual flows (trade, foreign direct investment, portfolio investment, and income payments to foreign nationals), and (ii) restrictions (hidden import barriers, mean tariff rate, taxes on international trade, and capital account restrictions. The social globalization index includes three groups of variables: (i) data on personal contact (telephone traffic, transfers, international tourism, foreign population, international letters), (ii) data on information flows (internet users, television, trade in newspapers), and (iii) data on cultural proximity (number of McDonald's restaurants, number of IKEA stores, trade in books). The political globalization index includes four individual variables: embassies in countries,

\footnotetext{
${ }^{4}$ The KOF index has been used in more than 100 empirical studies. On the empirical evidence see Potrafke (2015).
} 
membership in international organizations, participation in U.N. Security Council Missions, international treaties. The three sub-indices together define the overall index.

The overall KOF index is available for 187 countries, the political globalization subindex for 208 countries, the economic globalization sub-index for 148 countries and the social globalization sub-index for 193 countries. The overall index and the sub-indices assume values scaled from 1 (minimum of globalization) to 100 (maximum of globalization). The 2012 KOF index of globalization is available over the period 1970-2009.

\subsection{Descriptive analysis}

We relate the credit market deregulation indicators as measured by the average over the period 2006-2010 to the average KOF globalization index over the period 1970-2009. We relate the period 2006-2010 to the period 1970-2009 because we would like to examine how globalization over a longer period of time has influenced credit market deregulation in later years. We use the five-year-average 2006-2010 to ensure that outliers do not change the inferences. Figure 1 shows that the overall KOF globalization index is positively correlated with overall credit market deregulation. The correlation coefficient $\rho$ is 0.48 . Overall globalization is also positively correlated with the sub-indicators capturing ownership of banks deregulation and interest rate controls deregulation $(\rho=0.42$ and $\rho=0.39)$, but less strongly correlated with the sub-indicator of private sector credit deregulation $(\rho=0.18)$.

Figure 2 shows how credit market deregulation and globalization proceeded over time (arithmetic means across countries). The dashed line describes the average credit market deregulation in the last year of each 5-year period. The solid line describes overall globalization averaged over each 5 -year period. ${ }^{5}$ Credit market deregulation and globalization proceeded continuously over the period 1971-1990, and more rapidly since the 1990s. Credit market deregulation declined in the beginnings of the 1970s because of tightening interest rate

\footnotetext{
${ }^{5}$ Because of data availability, we relate credit market deregulation in 1970 to globalization in 1970.
} 
controls after the collapse of the Bretton Woods system. Credit market deregulation declined over the period 2006-2010 because private sector credit declined during the global financial crisis. The correlation between credit market deregulation and globalization over the period $1970-2010$ is $\rho=0.95$.

Table 1 shows descriptive statistics and the sources of the main variables used in the estimation below.

\section{Empirical strategy}

\subsection{Cross-sectional model and OLS}

Our empirical strategy in the cross-section follows Potrafke (2013), who investigates the influence of globalization on labor market institutions. The baseline cross-sectional model has the following form:

credit market deregulation $_{i}=\beta_{0}+\beta_{1}$ globalization $_{i}+\boldsymbol{\xi} \boldsymbol{x}_{\boldsymbol{i}}+u_{i}$,

where the dependent variable is the credit market deregulation indicator in country $i$ averaged over the period 2006-2010. Our main explanatory variable is the KOF globalization index averaged over the period 1970-2009. We also include the country-level control variables $\boldsymbol{x}_{\boldsymbol{i}}$, averaged over the same period: the logarithm of total population, to measure country size, the democracy-dictatorship indicator variable by Cheibub et al. $(2010)^{6}$ to measure political institutions, and legal origin dummy variables (La Porta et al., 1999). We distinguish between five legal origins: British (reference category), French, German, Socialist, and Scandinavian. The top panel of Table 1 shows summary statistics for all included variables in the crosssection. We first estimate the model (1) with ordinary least squares (OLS) and robust standard errors.

\footnotetext{
${ }^{6}$ The data by Cheibub et al. (2010) are only available until 2008.
} 
In alternative specifications, we measure globalization by the sub-indices for economic, social, and political globalization. We also estimate the model separately using overall credit market deregulation and three sub-indicators (ownership of banks, private sector credit, and interest rate controls) as the dependent variable.

\subsection{Geographical component of trade openness}

We then deal with the issue of reverse causality. It is conceivable that credit market deregulation also influences globalization because governments may, for example, deregulate credit markets in order to attract foreign investment. We use the geographic component of trade openness as proposed by Frankel and Romer (1999) as an IV for globalization. ${ }^{7}$ Our first stage regression takes the form:

globalization $_{i}=\alpha_{0}+\alpha_{1} \Omega_{i}^{F R}+\alpha_{2} \ln (\text { population })_{i}+\alpha_{3}$ democracy $_{i}+\varepsilon_{i}$,

where $\Omega_{i}^{F R}$ denotes predicted trade openness.

The IV $\Omega_{i}^{F R}$ is constructed in two steps. First, we estimate the following, modified gravity equation à la Frankel and Romer (1999), which explains bilateral trade openness (the sum of imports and exports as a share of GDP) of importing country $i$ with respect to country $j$ by several variables that are exogenous to country $i$ 's credit market institutions:

\footnotetext{
${ }^{7}$ The approach by Frankel and Romer (1999) has been criticized. Rodriguez and Rodrik (2000) show, for example, that the Frankel and Romer (1999) results are not robust to the inclusion of geographic controls in the second stage. To address this issue, we control for any observed or unobserved country-specific effects in the panel model.
} 
trade openness $_{i j}=\gamma_{0}+\gamma_{1} \ln (\text { distance })_{i j}+\gamma_{2} \ln (\text { population })_{i}+\gamma_{3} \ln (\text { population })_{j}$

$$
\begin{aligned}
& +\gamma_{4} \ln (\text { area })_{i}+\gamma_{5} \ln (\text { area })_{j}+\gamma_{6} \ln (\text { relative land border })_{i} \\
& +\gamma_{7} \ln (\text { relative land border })_{j}+\gamma_{8} \text { border }_{i j} \\
& +\gamma_{9} \text { border }_{i j} \times \ln \left(\text { distance }_{i j}+\gamma_{10} \text { border }_{i j} \times \ln \left(\text { population }_{i}\right.\right. \\
& +\gamma_{11} \text { border }_{i j} \times \ln (\text { population })_{j}+\gamma_{12} \text { border }_{i j} \times \ln (\text { area })_{i} \\
& +\gamma_{13} \operatorname{border}_{i j} \times \ln (\text { area })_{j}+\eta_{i j}
\end{aligned}
$$

We include the bilateral geographic distance, the size of the two countries measured by geographic area and population, and variables of relative land borders measured by land border/(land border + coastline) to consider how landlocked countries are. Following Frankel and Romer (1999), we also include a border dummy (equal to one for neighboring countries) and interaction terms of the border dummy with the size and distance measures.

We run the model (3) for the cross-section in each year $\tau$. We use Poisson Pseudo Maximum Likelihood (PPML) to estimate the gravity model (3). ${ }^{8}$ We obtain bilateral predicted trade openness from equation (3). The IV is then computed by summing over predicted bilateral openness for each importing country $i$ across all exporting countries and averaging over all $T$ available years during the period 1970-2008:

$$
\Omega_{i}^{F R}=\frac{1}{T} \sum_{\tau} \sum_{j} \text { trade } \widehat{\text { open }} \text { ess }_{l \jmath \tau}
$$

\subsection{Panel model and FE}

Our panel model exploits the time variation within countries to identify the effect of globalization on credit market deregulation. The panel data model is a time-variant version of model (2), which explains credit market deregulation in country $i$ and period $t$ by:

\footnotetext{
${ }^{8}$ We thank Gabriel Felbermayr and Jasmin Gröschl for providing their data and codes to compute predicted trade openness. The trade data come from the IMF's Direction of Trade Statistics (DoTS), nominal GDPs and populations are taken from the WDI (2009) and Barbieri (2002), and geographic variables come from CEPII's Geographic and Bilateral Distance Database. Data for 2009 are not yet available in the dataset by Felbermayr and Gröschl (2013) and Felbermayr et al. (2010).
} 
credit market deregulation $_{i t}=\beta_{0}+\beta_{1}$ globalization $_{i t}+\boldsymbol{\xi} \boldsymbol{x}_{i t}+u_{i t}$,

where credit market deregulation is measured in the last year of each 5-year period between 1996 and 2010 and the explanatory variable of interest globalization $_{i t}$ describes the KOF globalization index averaged over each 5-year period. We apply OLS to the withintransformed model, the so-called fixed effects (FE) model, to control for any observed or unobserved country-specific effects. The FE model eliminates important confounding factors, such as legal, cultural, or geographic country characteristics, that may affect both credit market deregulation and globalization. We also include the logarithm of population and the democracy variable as time-varying control variables $\boldsymbol{x}_{\boldsymbol{i t}}$ (5-year averages). When estimating model (4), we use standard errors robust to heteroskedasticity and serial correlation, clustered at the country level.

We also estimate the panel data model using the three sub-indicators for credit market deregulation as dependent variable and each of the globalization sub-indices as explanatory variable.

\subsection{Geography and natural disasters predicting trade openness}

Controlling for time-invariant country effects notwithstanding, credit market deregulation may also influence globalization. FE estimations of model (4) will therefore be biased if reverse causality is not dealt with. To deal with reverse causality in the panel model, we use the exogenous component of trade openness predicted by geography and natural disasters, as proposed by Felbermayr and Gröschl (2013), as an IV for globalization. Felbermayr and Gröschl (2013) show that natural disasters in one country influence trade openness of its trading partners, depending on the two countries' geographic proximity. ${ }^{9}$ For example, an earthquake hitting Haiti will increase the trade volumes of other countries to Haiti. Trade

\footnotetext{
${ }^{9}$ On panel data gravity models of international trade see Baltagi et al. (2014).
} 
increases will be larger, the closer an individual country is located to Haiti; e.g. trade increases will be stronger for Mexico than for India. In our model, the identifying assumption is that natural disasters in third countries have no effect on credit market deregulation of a country other than through trade. This IV strategy improves upon the approach by Frankel and Romer (1999) by exploiting exogenous time variation in trade openness, which allows for using the IV in a panel data model and controlling for unobserved country effects. ${ }^{10}$

Our empirical strategy differs in two respects from Felbermayr and Gröschl (2013). First, their identification strategy has been designed explicitly for the income-growth-nexus and not for examining whether globalization influences credit market deregulation. In any event, similar omitted variables that influence growth, such as geographic and cultural characteristics, would also bias the estimates of our equation (4). Employing the approach by Felbermayr and Gröschl (2013) is therefore also suitable in our context. Second, Felbermayr and Gröschl (2013) use predicted trade openness as an IV for a country's observed trade openness, defined as the ratio of imports plus exports over GDP. We show in Section 4 that the predicted trade share is also a relevant IV for the KOF globalization index, which includes several other facets of globalization in addition to trade flows (see Section 2.2).

The first stage regression takes the following form:

globalization $_{i t}=\alpha_{1} \Omega_{i t-1}^{F G}+\alpha_{2} \ln (\text { population })_{i t}+\alpha_{3}$ democracy $_{i t}+\delta_{t}+\delta_{i}+\varepsilon_{i t}$,

where $\Omega_{i t-1}^{F G}$ is the one-period lag of the predicted trade openness, our excluded variable in the second stage. We also estimate the model using the FE estimator, which controls for any timeinvariant country characteristics, with standard errors clustered by country.

The IV is constructed in two steps. First, we estimate a reduced gravity model on a large sample of country pairs that explains bilateral trade openness (sum of imports and

\footnotetext{
${ }^{10}$ Feyrer (2009) also uses a time-varying geography-based IV for trade openness: the availability of airport infrastructure. The advantage of the IV proposed by Felbermayr and Gröschl (2013) compared to Feyrer's (2009) approach is that natural disasters are beyond doubt exogenous to the dependent variable.
} 
exports as a share of GDP) of country $i$ to trade with country $j$ in year $\tau$ by natural disasters in country $j$, population, bilateral geographic variables (the logarithm of bilateral distance and a border dummy), and several interactions of the disaster variable: ${ }^{11}$

$$
\begin{aligned}
\text { trade openness }_{i j \tau} & =\lambda_{0}+\lambda_{1} \ln (\text { population })_{i \tau}+\lambda_{2} \ln \left(\text { population }_{j \tau}\right. \\
& +\lambda_{3} \ln \left({\text { distance })_{i j}}+\lambda_{4} \text { border }_{i j}+\lambda_{5} \text { disaster }_{j \tau}\right. \\
& +\lambda_{6} \text { disaster }_{j \tau} \times \text { border }_{i j}+\lambda_{7} \text { disaster }_{j \tau} \times \ln \left(\text { population }_{j \tau}\right. \\
& +\lambda_{8} \text { disaster }_{j \tau} \times \ln \left(\text { area }_{j \tau}+\lambda_{9} \text { disaster }_{j \tau} \times \ln (\text { dist.fin.center })_{j \tau}\right. \\
& +\delta_{i}+\delta_{j}+\delta_{\tau}+\eta_{i j \tau} .
\end{aligned}
$$

The interaction terms take into account that disasters in large countries, neighboring countries, and countries that are closer to financial centers have stronger effects on bilateral openness. We also include importer, exporter, and year dummies. The model is estimated using Poisson Pseudo Maximum Likelihood (PPML) with standard errors clustered by country pair. Because we use data on all available countries and years for 1950-2008, our estimates of (6) are identical to Felbermayr and Gröschl (2013, their Table 2, column 2).

From (6), we obtain predicted values for yearly bilateral trade openness: trade $\widehat{\text { open }} n e s s_{l \jmath \tau}$. We aggregate the predicted values over all trading partners by importing country and year and average over 5-year periods to obtain the predicted trade openness variable

$$
\Omega_{i t}^{F G}=\frac{1}{5} \sum_{\tau \in t} \sum_{j} \text { trade } \widehat{\text { open }} \text { ess }_{l j \tau} .
$$

We use $\Omega_{i t-1}^{F G}$ as an IV for globalization in equation (5). We report results based on the preferred IV by Felbermayr and Gröschl (2013), which includes only large-scale, truly

\footnotetext{
${ }^{11}$ We use the data provided by Felbermayr and Gröschl (2013) and Felbermayr et al. (2010) on geographic variables their data on natural disasters, originating in the Emergency Events database (EM-DAT), and on distance to financial centers, which is based on Rose and Spiegel (2009).
} 
exogenous natural disasters in third countries. We discuss results based on alternative IVs in Section 4.3. 


\section{Results}

\subsection{Cross-sectional results}

Table 2 shows the cross-sectional regression results for the overall credit market deregulation indicator. The results from estimating the model by OLS indicate that globalization was positively associated with credit market deregulation. The coefficient of the overall globalization variable is statistically significant at the $1 \%$ level in column (1). This result contrasts with the previous finding by Heinemann and Tanz (2008), who used a much smaller sample of 54 countries.

By using predicted trade openness as an IV and estimating the model by 2SLS, the results do however not confirm that globalization influenced overall credit market deregulation. The coefficients of the instrumented overall, economic, social and political KOF index of globalization do not turn out to be statistically significant in columns (2) to (5). The F-test on the excluded instrument can be rejected at the $1 \%$ level and the F-statistic is above the Stock and Yogo (2005) 10\% critical value in columns (2) to (4). The partial R-squared indicates that predicted trade openness explains a substantial share of variation in the globalization variables in the first stage regressions.

Table 3 shows the results when we use the sub-indicators of credit market deregulation as dependent variables. Globalization was also positively associated with the ownership banks deregulation sub-indicator when we estimate the model by OLS. The coefficient of the overall globalization variable is statistically significant at the $1 \%$ level in column (1). By using the predicted trade openness as IV and estimating the model by 2SLS, the results again do not show that globalization influenced the ownership banks deregulation sub-indicator. The results in columns (3) and (4) do not show that globalization influenced the private sector credit deregulation indicator. The results in columns (5) and (6) show however that globalization had a positive influence on interest rate controls deregulation. The globalization 
variables are statistically significant at the $1 \%$ level. The numerical meaning of the effect in column (6) is, for example, that when the KOF index of globalization increases by one standard deviation (about 16 points on a scale from 1 to 100) the interest rate controls deregulation indicator increases by about 0.6 standard deviations.

\subsection{Panel results}

Table 4 shows the results of the panel data model. The coefficient of the KOF index for overall globalization is positive and statistically significant at the $1 \%$ level (column 1) and thus corroborates the positive long-run correlation between globalization and credit market deregulation as shown in the cross-sectional model. When we restrict the observation period to the period 1996-2010 (column 2), the coefficient estimate of KOF index of globalization is quite similar to the coefficient estimate in column (1) and remains statistically significant at the $1 \%$ level.

We use the one-period lag of the predicted trade openness $\Omega_{i t-1}^{F G}$ as an IV for overall globalization over the period 1996-2010 in column (3). The 2SLS estimate does not confirm the positive correlation. The estimated coefficient of globalization on credit market deregulation has a negative sign and does not turn out to be statistically significant at any conventional level. In the first stage, the IV has a positive and significant effect on globalization with an F-statistic above the Stock and Yogo (2005) 15\% critical value. These findings suggest that the partial correlation described in the OLS model does not reflect a causal effect of globalization on credit market deregulation. We do not report 2SLS estimates based on the full panel for the period 1970-2010 because the predicted trade share does not have a strong effect on the KOF globalization index in the earlier periods, indicating a weak IV problem over the period 1970-2010. However, the IV is strong for the period 1996-2010 and the OLS and 2SLS results are perfectly in line with the cross-sectional evidence. 
Columns (4) to (6) show the results for the globalization sub-indices. As expected, the predicted trade openness is a strong IV for economic globalization with an F-statistic well above the $10 \%$ critical value. The instrumented effect of economic globalization on credit market deregulation in the second stage does not turn out to be statistically significant. In a similar vein, the coefficients of political and social globalization do not turn out to be statistically significant. The coefficient estimates of political and social globalization need to be interpreted with caution, however, because the IV is weak with F-statistics below 5.5.

We use the three sub-indicators of credit market deregulation as dependent variables and re-estimate the panel models for the period 1996-2010 (Table 5). The FE models suggest a positive correlation of globalization with bank ownership and private sector credit deregulation. When we estimate the models by 2SLS, the globalization variable lacks statistical significance in any specification.

\subsection{Robustness analysis}

We have tested the robustness of our results in many ways. In the cross-section, we have replaced the globalization indices as measured over the period 1970-2009 by the average over the period 1970-2005. Inferences do not change.

We have used alternative approaches to constructing the instrument in the panel. First, we have used data over the period 1966-2008 (or 1986-2008) when estimating the reduced gravity equation (6) because data in previous years may be less reliable, in particular because of missing values. ${ }^{12}$ Inferences regarding the globalization variables do not change. Second, we have used alternative definitions of disasters, as suggested by Felbermayr and Gröschl (2013). Using the alternative IVs, inferences do not change.

\footnotetext{
${ }^{12}$ International goods trade data differs across data sources. Differences in data sources may well translate into econometric estimates in gravity models (Egger and Wolfmayr, 2014).
} 
We have also included domestic disasters as an explanatory variable in the second stage. Domestic disasters do not turn out to be statistically significant. Inferences do not change.

We have estimated the FE and 2SLS panel data models using robust standard errors not clustered by country and using classical standard errors. Inferences do not change. 


\section{Conclusion}

Because lax credit market regulation has been attributed to have induced the financial crisis starting in 2007 (competition of laxity, Sinn, 2010), it is conceivable that globalization also contributed to the financial crisis by triggering credit market deregulation. By using predicted trade openness as an IV for globalization in cross-sectional and panel data models, our results do not show that the positive correlation between globalization and credit market deregulation is causal. ${ }^{13}$ We have derived our results based on the credit market deregulation indicators by the Fraser Institute. Our results indicate that future research should investigate in more detail (i) what explains the deregulation of capital markets that is observed over the past decades and (ii) which role globalization has played in the financial and public debt crisis. ${ }^{14}$

Many experts agree that financial markets need to be regulated more tightly (see, e.g., Chinn and Frieden, 2011, and Sinn, 2010). Because capital is mobile, national governments may however not individually regulate financial markets in different manners, but coordinate policies across countries. A keen alternative is that national governments may delegate more of their responsibilities to international organizations. An issue is to which extent global governance would ameliorate credit market regulation and whether domestic governments are indeed willing to delegate competences. ${ }^{15}$

\footnotetext{
${ }^{13}$ In a similar vein, globalization has not been shown to induce labor market deregulation (see Felbermayr et al., 2012, and Potrafke, 2013).

${ }^{14}$ Lane (2013) explores how financial globalization gave rise to the origination of the crisis. A measure of financial globalization is the sum of foreign assets and foreign liabilities (as a share of GDP). Foreign investors participated and thus triggered the securitization boom in the United States. Financial globalization also fostered differences in credit growth and current account imbalances across countries. "...much more remains to be done in terms of designing global, regional and national policy frameworks that can cope with high levels of international financial integration." (p. 577).

${ }^{15}$ See Frieden (2012) on global governance and Frieden et al. (2012) on problems of international economic cooperation.
} 


\section{References}

Aggarwal, R., and Goodell, J.W. (2009). Markets and institutions in financial intermediation: National characteristics as determinants. Journal of Banking and Finance 33(1), 17701780.

Baltagi, B., Egger, P., and Pfaffermayr, M. (2014). Panel data gravity models of international trade. CESifo Working Papers No. 4616. Munich.

Barbieri, K. (2002). The Liberal Illusion: Does Trade Promote Peace? University of Michigan Press.

Cheibub, J., Gandhi, J., and Vreeland, J.R. (2010). Democracy and dictatorship revisited. Public Choice 143(1-2), 67-101.

Chinn, M.D., and Frieden, J.A. (2011). Lost decades. W.W. Norton \& Company, New York.

Dreher, A. (2006). Does globalization affect growth? Evidence from a new index of globalization. Applied Economics 38(1), 1091-1110.

Dreher, A., Sturm, J.-E., and Ursprung H.W. (2008a). The impact of globalization on the composition of government expenditures: Evidence from panel data. Public Choice 134, 263-292.

Dreher, A., Gaston N., and Martens P. (2008b). Measuring globalization - Gauging its consequences. Berlin: Springer.

Egger, P., and Wolfmayr, Y. (2014). What economists should know about international goods trade data. WIFO Working Papers 475. Vienna.

Felbermayr, G.J., and Gröschl, J.K. (2013). Natural disasters and the effect of trade on income: A new panel IV approach. European Economic Review 58, 18-30.

Felbermayr, G.J., Hiller, S., and Sala, D. (2010). Does immigration boost per capita income? Economics Letters 107(2), 177-179.

Felbermayr, G.J., Larch, M., and Lechthaler, W. (2012). Endogenous labor market institutions in an open economy. International Review of Economics and Finance 23(June), 30-45.

Feyrer, J. (2009). Trade and Income-exploiting time series in geography. NBER Working Paper 14910.

Frankel, J.A., and Romer, D. (1999). Does trade cause growth? American Economic Review 89(3), 379-399.

Frieden, J. (2012). Global economic governance after the crisis. Perspektiven der Wirtschaftspolitik 13, 1-12. 
Frieden, J., Pettis, M., Rodrik, D. and Zedillo, E. (2012). After the fall: the future of global cooperation. Geneva Reports on the World Economy 14. International Center for Monetary and Banking Studies (ICMB). Geneva.

Gwartney, J., Hall, J., and Lawson, R. (2012). Economic freedom of the world: 2012 annual report. The Fraser Institute, Vancouver.

Heinemann, F., and Tanz, B. (2008). The impact of trust on reforms. Journal of Economic Policy Reform 11(3), 173-185.

Kauder, B., and Potrafke, N. (2015). Globalization and social justice in OECD countries. Review of World Economics/Weltwirtschaftliches Archiv 151(2), 353-376.

Klomp, J. (2010). Causes of banking crises revisited. North American Journal of Economics and Finance 21(1), 72-87.

La Porta, R., Lopez-di-Silanes, F., Shleifer, A., and Vishny, R. (1999). The quality of government. Journal of Law, Economics and Organization 15(1), 222-279.

Lane, P.R. (2013). Financial globalization and the crisis. Open Economies Review 24(3), 555-580.

Law, H.L., Azman-Saini, W.N.W., and Tan, H.B. (2014). Economic globalization and financial development in East Asia: A panel cointegration and causality analysis. Emerging Markets Finance and Trade 50(1), 210-225.

Law, H.L., Tan, H.B, and Azman-Saini, W.N.W. (2015). Globalisation, institutional reforms and financial development in East Asian economies. World Economy 38(2), 379-398.

Meinhard, S., and Potrafke, N. (2012). The globalization-welfare state nexus reconsidered. Review of International Economics 20(2), 271-287.

Mishkin, F.S. (2009). Globalization and financial development. Journal of Development Economics 89, 164-169.

Pierucci, E., and Ventura, L. (2012). International risk sharing and globalization. MPRA Paper No. 35869, Munich.

Potrafke, N. (2013). Globalization and labor market institutions: International empirical evidence. Journal of Comparative Economics 41(3), 829-842.

Potrafke, N. (2015). The evidence on globalisation. World Economy 38(3), 509-552.

Rodriguez, F., and Rodrik, D. (2000). Trade policy and economic growth: A skeptics guide to the cross-national evidence. NBER Macroeconomics Annual.

Rose, A., and Spiegel, M. (2009). International financial remoteness and macroeconomic volatility. Journal of Development Economics 89(2), 250-257. 
Schulze, G.G., and Ursprung, H.W. (1999). Globalisation of the economy and the nation state. World Economy 22(3), 295-352.

Sinn, H.-W. (1997). The selection principle and market failure in systems competition. Journal of Public Economics 66(2), 247-274.

Sinn, H.-W. (2003). The new systems competition. Blackwell, Oxford.

Sinn, H.-W. (2010). Casino capitalism: How the financial crisis came about and what needs to be done now. Oxford University Press, Oxford.

Stock, J., and Yogo, M. (2005). Testing for weak instruments in linear IV regression. in: Andrews, D., and Stock, J. (Ed.). Identification and inference for econometric models: Essays in honour of Thomas Rothenberg. Cambridge: Cambridge Universtiy Press. 80-108.

Ursprung, H.W. (2008). Globalisation and the welfare state. in: S.N. Durlauf, and L.E. Blume (Ed.), The New Palgrave Dictionary of Economics, Second edition. Köln: Palgrave Macmillan. 
Figure 1. Credit market deregulation and globalization in the cross-section.

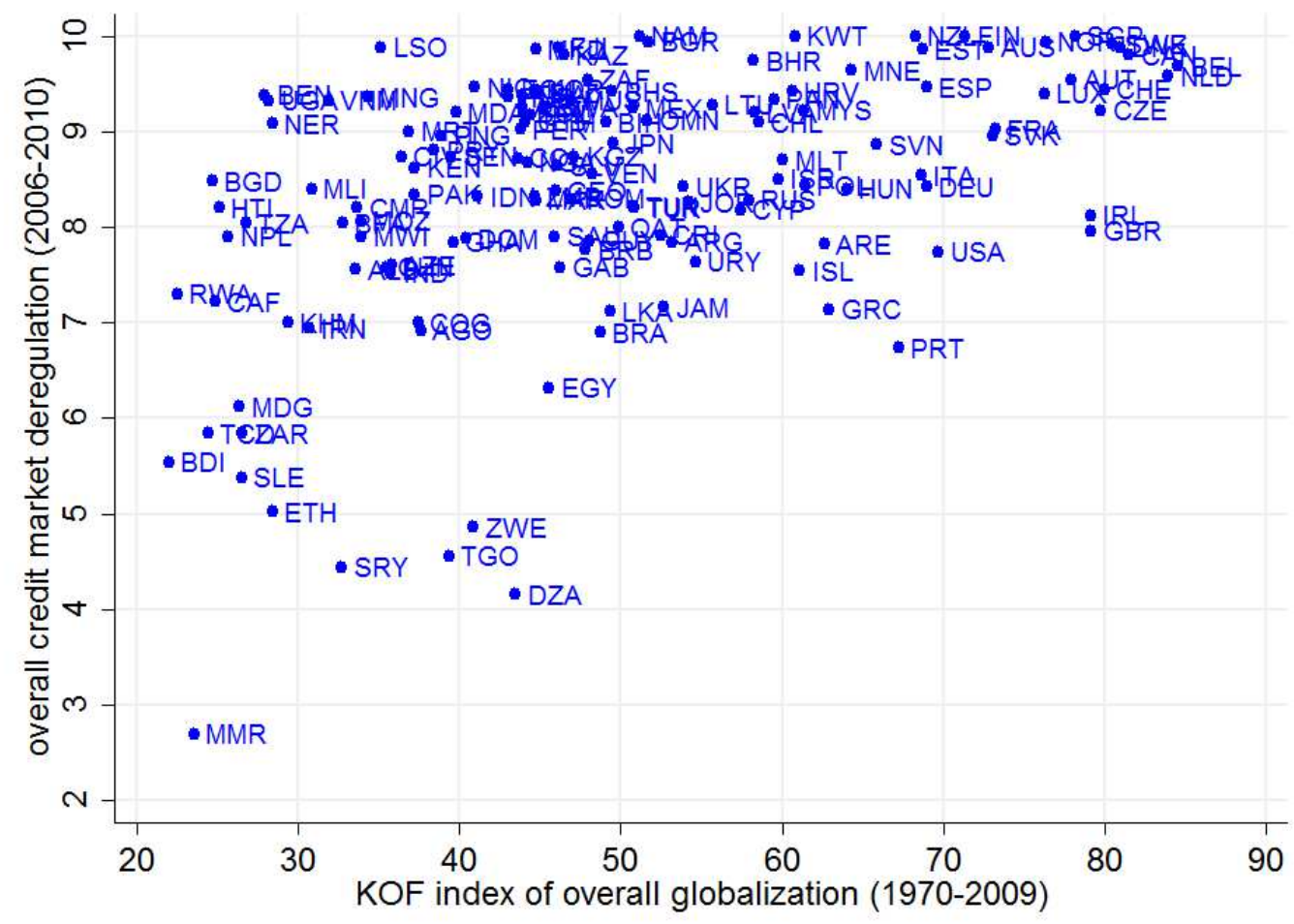

The figure shows credit market deregulation (average 2006-2010) and globalization (average 1970-2009) by country. The correlation coefficient is 0.48 .

Figure 2. Credit market deregulation and globalization in the panel.

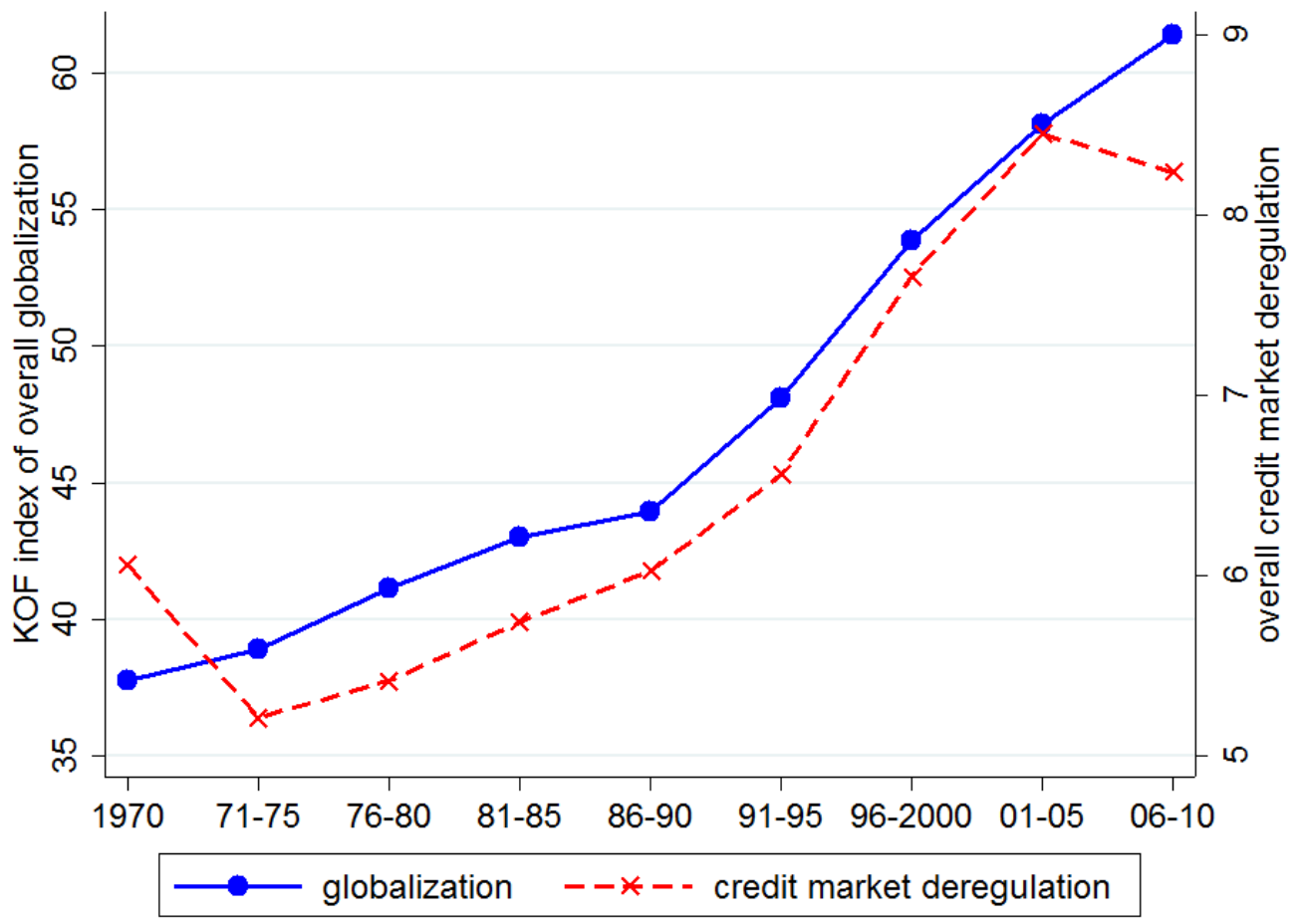

The figure shows how globalization (left axis) and credit market deregulation (right axis) changed over time. Globalization is measured as the 5-year period average. Credit market deregulation is measured in the last year of each period. The correlation coefficient is 0.95 . 
Table 1. Descriptive statistics and sources.

\begin{tabular}{|c|c|c|c|c|c|c|}
\hline Variable & $\begin{array}{l}\text { Obser- } \\
\text { vations }\end{array}$ & Mean & $\begin{array}{l}\text { Std. } \\
\text { Dev. }\end{array}$ & Min & Max & Source \\
\hline \multicolumn{7}{|c|}{ Cross-sectional dataset (1970-2010 vs. 2006-2010) } \\
\hline $\begin{array}{l}\text { overall credit market } \\
\text { deregulation }(2006-2010)\end{array}$ & 142 & 8.39 & 1.34 & 2.7 & 10 & Gwartney et al. (2012) \\
\hline $\begin{array}{l}\text { credit market deregulation: } \\
\text { ownership banks }(2006-2010)\end{array}$ & 136 & 7.68 & 2.82 & 0 & 10 & Gwartney et al. (2012) \\
\hline $\begin{array}{l}\text { credit market deregulation: } \\
\text { private sector credit (2006-2010) }\end{array}$ & 142 & 8.22 & 1.73 & 2.4 & 10 & Gwartney et al. (2012) \\
\hline $\begin{array}{l}\text { credit market deregulation: } \\
\text { interest rate controls (2006- } \\
2010)\end{array}$ & 140 & 9.19 & 1.31 & 0 & 10 & Gwartney et al. (2012) \\
\hline $\begin{array}{l}\text { overall globalization (1970- } \\
\text { 2009) }\end{array}$ & 141 & 48.96 & 15.84 & 22.01 & 84.54 & $\begin{array}{l}\text { Dreher (2006) and Dreher et } \\
\text { al. }(2008 b)\end{array}$ \\
\hline $\begin{array}{l}\text { economic globalization (1970- } \\
\text { 2009) }\end{array}$ & 139 & 50.59 & 17.08 & 15.65 & 94.98 & $\begin{array}{l}\text { Dreher (2006) and Dreher et } \\
\text { al. (2008b) }\end{array}$ \\
\hline social globalization (1970-2009) & 141 & 41.38 & 20.31 & 8.33 & 83.73 & $\begin{array}{l}\text { Dreher (2006) and Dreher et } \\
\text { al. }(2008 b)\end{array}$ \\
\hline $\begin{array}{l}\text { political globalization (1970- } \\
2009)\end{array}$ & 141 & 57.55 & 18.54 & 19.37 & 96.57 & $\begin{array}{l}\text { Dreher (2006) and Dreher et } \\
\text { al. (2008b) }\end{array}$ \\
\hline $\begin{array}{l}\text { predicted trade openness } \\
(1970-2008) \Omega_{i}^{F R}\end{array}$ & 135 & 66.28 & 32.99 & 17.01 & 204.16 & $\begin{array}{l}\text { Authors' calculations based on } \\
\text { data by Felbermayr and } \\
\text { Gröschl (2013) }\end{array}$ \\
\hline In population (1970-2009) & 143 & 9.02 & 1.61 & 5.29 & 13.92 & $\begin{array}{l}\text { PWT 7.0, Summers and } \\
\text { Heston (1991) }\end{array}$ \\
\hline democracy (1970-2008) & 143 & 0.50 & 0.42 & 0 & 1 & Cheibub et al. (2010) \\
\hline British legal origin & 143 & 0.29 & 0.45 & 0 & 1 & La Porta et al. (1999) \\
\hline French legal origin & 143 & 0.44 & 0.50 & 0 & 1 & La Porta et al. (1999) \\
\hline Socialist legal origin & 143 & 0.20 & 0.40 & 0 & 1 & La Porta et al. (1999) \\
\hline German legal origin & 143 & 0.04 & 0.20 & 0 & 1 & La Porta et al. (1999) \\
\hline Scandinavian legal origin & 143 & 0.03 & 0.18 & 0 & 1 & La Porta et al. (1999) \\
\hline
\end{tabular}

Panel dataset (1996-2010)

\begin{tabular}{|c|c|c|c|c|c|c|}
\hline $\begin{array}{l}\text { overall credit market } \\
\text { deregulation }\end{array}$ & 376 & 8.10 & 1.59 & 1.4 & 10 & Gwartney et al. (2012) \\
\hline $\begin{array}{l}\text { credit market deregulation: } \\
\text { ownership banks }\end{array}$ & 362 & 7.08 & 3.19 & 0 & 10 & Gwartney et al. (2012) \\
\hline $\begin{array}{l}\text { credit market deregulation: } \\
\text { private sector credit }\end{array}$ & 374 & 8.11 & 2.11 & 0 & 10 & Gwartney et al. (2012) \\
\hline $\begin{array}{l}\text { credit market deregulation: } \\
\text { interest rate controls }\end{array}$ & 366 & 9.12 & 1.51 & 0 & 10 & Gwartney et al. (2012) \\
\hline overall globalization & 376 & 59.11 & 16.77 & 23.51 & 92.63 & $\begin{array}{l}\text { Dreher (2006) and Dreher et } \\
\text { al. }(2008 b)\end{array}$ \\
\hline economic globalization & 376 & 59.82 & 18.09 & 18.32 & 97.53 & $\begin{array}{l}\text { Dreher (2006) and Dreher et } \\
\text { al. }(2008 b)\end{array}$ \\
\hline social globalization & 376 & 50.11 & 22.67 & 8.99 & 92.61 & $\begin{array}{l}\text { Dreher (2006) and Dreher et } \\
\text { al. }(2008 b)\end{array}$ \\
\hline political globalization & 376 & 70.95 & 17.66 & 27.91 & 98.10 & $\begin{array}{l}\text { Dreher (2006) and Dreher et } \\
\text { al. }(2008 b)\end{array}$ \\
\hline $\begin{array}{l}\text { lag predicted trade openness } \\
\Omega_{i t-1}^{F G}\end{array}$ & 376 & 65.37 & 37.34 & 16.80 & 280.60 & $\begin{array}{l}\text { Authors' calculations based on } \\
\text { data by Felbermayr and } \\
\text { Gröschl (2013) }\end{array}$ \\
\hline In population & 376 & 9.33 & 1.61 & 5.46 & 14.09 & $\begin{array}{l}\text { PWT 7.0, Summers and } \\
\text { Heston (1991) }\end{array}$ \\
\hline democracy & 376 & 0.67 & 0.46 & 0 & 1 & Cheibub et al. (2010) \\
\hline
\end{tabular}


Table 2: Cross-section regression results

Dependent variable: Overall credit market deregulation (2006-2010).

Instrumental variable: Predicted trade openness (Frankel and Romer, 1999).

\begin{tabular}{|c|c|c|c|c|c|}
\hline & (1) & (2) & (3) & (4) & $(5)$ \\
\hline Estimation method & OLS & 2 SLS & 2 SLS & 2 SLS & 2 SLS \\
\hline $\begin{array}{l}\text { overall globalization } \\
(1970-2009)\end{array}$ & $\begin{array}{l}0.0247 * * * \\
(3.54)\end{array}$ & $\begin{array}{l}0.0100 \\
(0.64)\end{array}$ & & & \\
\hline $\begin{array}{l}\text { economic globalization } \\
(1970-2009)\end{array}$ & & & $\begin{array}{l}0.00953 \\
(0.64)\end{array}$ & & \\
\hline $\begin{array}{l}\text { social globalization } \\
(1970-2009)\end{array}$ & & & & $\begin{array}{l}0.00762 \\
(0.64)\end{array}$ & \\
\hline $\begin{array}{l}\text { political globalization } \\
(1970-2009)\end{array}$ & & & & & $\begin{array}{l}0.0213 \\
(0.64)\end{array}$ \\
\hline In population (1970-2009) & $\begin{array}{c}-0.109 * * \\
(-2.16)\end{array}$ & $\begin{array}{c}-0.0985^{*} \\
(-1.91)\end{array}$ & $\begin{array}{c}-0.0743 \\
(-1.03)\end{array}$ & $\begin{array}{c}-0.0833 \\
(-1.31)\end{array}$ & $\begin{array}{l}-0.235 \\
(-1.14)\end{array}$ \\
\hline democracy (1970-2008) & $\begin{array}{l}0.399 \\
(1.53)\end{array}$ & $\begin{array}{c}0.748 * * \\
(1.97)\end{array}$ & $\begin{array}{c}0.795^{* *} \\
(2.35)\end{array}$ & $\begin{array}{c}0.762 * * \\
(2.10)\end{array}$ & $\begin{array}{l}0.544 \\
(0.81)\end{array}$ \\
\hline French legal origin & $\begin{array}{l}-0.335 \\
(-1.38)\end{array}$ & $\begin{array}{l}-0.205 \\
(-0.80)\end{array}$ & $\begin{array}{l}-0.191 \\
(-0.71)\end{array}$ & $\begin{array}{l}-0.193 \\
(-0.73)\end{array}$ & $\begin{array}{l}-0.296 \\
(-1.22)\end{array}$ \\
\hline Socialist legal origin & $\begin{array}{l}0.267 \\
(1.16)\end{array}$ & $\begin{array}{l}0.327 \\
(1.46)\end{array}$ & $\begin{array}{l}0.319 \\
(1.43)\end{array}$ & $\begin{array}{l}0.303 \\
(1.37)\end{array}$ & $\begin{array}{l}0.447 \\
(1.37)\end{array}$ \\
\hline German legal origin & $\begin{array}{l}0.245 \\
(0.72)\end{array}$ & $\begin{array}{l}0.421 \\
(1.40)\end{array}$ & $\begin{array}{l}0.457 \\
(1.58)\end{array}$ & $\begin{array}{l}0.393 \\
(1.22)\end{array}$ & $\begin{array}{l}0.421 \\
(1.38)\end{array}$ \\
\hline Scandinavian legal origin & $\begin{array}{c}0.0305 \\
(0.06)\end{array}$ & $\begin{array}{l}0.341 \\
(0.70)\end{array}$ & $\begin{array}{l}0.413 \\
(0.89)\end{array}$ & $\begin{array}{l}0.376 \\
(0.77)\end{array}$ & $\begin{array}{r}-0.0242 \\
(-0.03)\end{array}$ \\
\hline $\begin{array}{l}\text { Observations } \\
\text { R-squared }\end{array}$ & $\begin{array}{c}137 \\
0.262\end{array}$ & $\begin{array}{c}132 \\
0.251\end{array}$ & $\begin{array}{c}130 \\
0.254\end{array}$ & $\begin{array}{c}132 \\
0.246\end{array}$ & $\begin{array}{c}132 \\
0.216\end{array}$ \\
\hline First stage & & OLS & OLS & OLS & OLS \\
\hline $\begin{array}{l}\text { Predicted trade openness } \\
(1970-2008) \Omega_{i}^{F R}\end{array}$ & & $\begin{array}{c}0.315 * * * \\
(5.45)\end{array}$ & $\begin{array}{c}0.343 * * * \\
(5.68)\end{array}$ & $\begin{array}{c}0.415 * * * \\
(4.82)\end{array}$ & $\begin{array}{c}0.149 * * \\
(2.48)\end{array}$ \\
\hline $\begin{array}{l}\text { Partial R-squared } \\
\text { F-test on excl. instrument } \\
\text { F-test, p-value }\end{array}$ & & $\begin{array}{c}0.1890 \\
29.67 \\
0.0000\end{array}$ & $\begin{array}{c}0.1674 \\
32.23 \\
0.0000\end{array}$ & $\begin{array}{c}0.2199 \\
23.21 \\
0.0000\end{array}$ & $\begin{array}{c}0.0416 \\
6.17 \\
0.0144\end{array}$ \\
\hline
\end{tabular}

t-statistics for OLS estimations and z-statistics for 2LSLS estimations reported in parenthesis (robust standard errors).

Asterisks indicate significance levels: $* \mathrm{p}<0.1, * * \mathrm{p}<0.05, * * * \mathrm{p}<0.01$.

Stock and Yogo (2005) 10\% critical value: 16.38; $15 \%$ critical value: $8.96 ; 20 \%$ critical value: $6.66 ; 25 \%$ critical value: 5.53 . 
Table 3: Cross-section regression results for sub-indicators of credit market deregulation Instrumental variable: Predicted trade openness (Frankel and Romer, 1999).

\begin{tabular}{|c|c|c|c|c|c|c|}
\hline & $(1)$ & $(2)$ & (3) & (4) & $(5)$ & $(6)$ \\
\hline Dependent variable & \multicolumn{2}{|c|}{ banks ownership } & \multicolumn{2}{|c|}{ private sector credit } & \multicolumn{2}{|c|}{ interest rate controls } \\
\hline Estimation method & OLS & 2 SLS & OLS & $2 \mathrm{SLS}$ & OLS & $2 \mathrm{SLS}$ \\
\hline overall globalization & $0.0490 * * *$ & $\begin{array}{l}-0.0259 \\
(-0.67)\end{array}$ & $\begin{array}{c}0.00980 \\
(085)\end{array}$ & $\begin{array}{c}-0.00550 \\
(-020)\end{array}$ & $0.0252 * * *$ & $0.0538 * * *$ \\
\hline In population (1970-2009) & $\begin{array}{c}-0.451 * * * \\
(-3.50)\end{array}$ & $\begin{array}{c}-0.471 * * * \\
(-2.89)\end{array}$ & $\begin{array}{l}0.0215 \\
(0.22)\end{array}$ & $\begin{array}{c}0.0489 \\
(0.52)\end{array}$ & $\begin{array}{c}0.00867 \\
(0.18)\end{array}$ & $\begin{array}{c}0.0308 \\
(0.52)\end{array}$ \\
\hline democracy (1970-2008) & $\begin{array}{l}0.945 \\
(1.62)\end{array}$ & $\begin{array}{c}2.228 * * \\
(2.37)\end{array}$ & $\begin{array}{c}-0.0963 \\
(-0.24)\end{array}$ & $\begin{array}{l}0.284 \\
(0.46)\end{array}$ & $\begin{array}{l}0.424 \\
(1.47)\end{array}$ & $\begin{array}{c}0.00493 \\
(0.02)\end{array}$ \\
\hline French legal origin & $\begin{array}{c}-1.185 * * \\
(-2.24)\end{array}$ & $\begin{array}{c}-1.215^{* *} \\
(-2.09)\end{array}$ & $\begin{array}{l}0.162 \\
(0.44)\end{array}$ & $\begin{array}{l}0.355 \\
(0.93)\end{array}$ & $\begin{array}{l}-0.397 \\
(-1.28)\end{array}$ & $\begin{array}{l}-0.258 \\
(-0.70)\end{array}$ \\
\hline Socialist legal origin & $\begin{array}{l}-0.251 \\
(-0.51)\end{array}$ & $\begin{array}{c}-0.0358 \\
(-0.06)\end{array}$ & $\begin{array}{l}0.655^{*} \\
(1.79)\end{array}$ & $\begin{array}{c}0.804 * * \\
(2.22)\end{array}$ & $\begin{array}{l}0.0941 \\
(0.34)\end{array}$ & $\begin{array}{c}0.0767 \\
(0.25)\end{array}$ \\
\hline German legal origin & $\begin{array}{l}-1.149 \\
(-1.28)\end{array}$ & $\begin{array}{l}-0.459 \\
(-0.52)\end{array}$ & $\begin{array}{l}1.335^{* * *} \\
(2.61)\end{array}$ & $\begin{array}{l}1.542 * * * \\
(2.98)\end{array}$ & $\begin{array}{l}0.0778 \\
(0.26)\end{array}$ & $\begin{array}{l}-0.142 \\
(-0.34)\end{array}$ \\
\hline Scandinavian legal origin & $\begin{array}{l}-0.467 \\
(-0.96)\end{array}$ & $\begin{array}{l}0.794 \\
(1.01)\end{array}$ & $\begin{array}{l}0.621 \\
(0.58)\end{array}$ & $\begin{array}{l}1.005 \\
(0.99)\end{array}$ & $\begin{array}{c}-0.668 * \\
(-1.89)\end{array}$ & $\begin{array}{c}-1.080 * * * \\
(-3.39)\end{array}$ \\
\hline Observations & 131 & 127 & 137 & 132 & 135 & 130 \\
\hline R-squared & 0.294 & 0.166 & 0.0495 & 0.0504 & 0.196 & 0.130 \\
\hline First stage & & OLS & & OLS & & OLS \\
\hline $\begin{array}{l}\text { Predicted trade openness } \\
(1970-2008) \Omega_{i}^{F R}\end{array}$ & & $\begin{array}{c}0.306^{* * * *} \\
(5.08)\end{array}$ & & $\begin{array}{c}0.315 * * * \\
(5.45)\end{array}$ & & $\begin{array}{c}0.312 * * * \\
(5.31)\end{array}$ \\
\hline Partial R-squared & & 0.1732 & & 0.1890 & & 0.1835 \\
\hline F-test on excl. instrument & & 25.79 & & 29.67 & & 28.22 \\
\hline F-test, p-value & & 0.0000 & & 0.0000 & & 0.0000 \\
\hline
\end{tabular}

t-statistics for OLS estimations and z-statistics for 2LSLS estimations reported in parenthesis (robust standard errors).

Asterisks indicate significance levels: $* \mathrm{p}<0.1, * * \mathrm{p}<0.05, * * * \mathrm{p}<0.01$.

Stock and Yogo (2005) 10\% critical value: $16.38 ; 15 \%$ critical value: $8.96 ; 20 \%$ critical value: $6.66 ; 25 \%$ critical value: 5.53 . 
Table 4: Panel regression results

Dependent variable: Overall credit market deregulation.

Instrumental variable: Lag predicted trade openness (Felbermayr and Gröschl, 2013).

\begin{tabular}{|c|c|c|c|c|c|c|}
\hline & $(1)$ & $(2)$ & (3) & (4) & $(5)$ & $(6)$ \\
\hline Time period & $\begin{array}{l}1970- \\
2010\end{array}$ & \multicolumn{5}{|c|}{$1996-2010$} \\
\hline Estimation method & FE & $\mathrm{FE}$ & 2SLS & 2SLS & 2SLS & 2SLS \\
\hline \multirow[t]{2}{*}{ overall globalization } & $0.0999 * * *$ & $0.112 * * *$ & -0.0571 & & & \\
\hline & $(4.32)$ & $(3.77)$ & $(-0.29)$ & & & \\
\hline \multirow[t]{2}{*}{ economic globalization } & & & & -0.0399 & & \\
\hline & & & & $(-0.30)$ & & \\
\hline \multirow[t]{2}{*}{ political globalization } & & & & & -0.0632 & \\
\hline & & & & & $(-0.28)$ & \\
\hline \multirow[t]{2}{*}{ social globalization } & & & & & & -0.0887 \\
\hline & & & & & & $(-0.29)$ \\
\hline \multirow[t]{2}{*}{ In population } & 0.155 & $3.152 * *$ & $3.047 * *$ & $2.982 * *$ & 3.642 & 2.602 \\
\hline & $(0.24)$ & $(2.30)$ & $(1.92)$ & $(1.87)$ & $(1.37)$ & $(1.12)$ \\
\hline \multirow[t]{2}{*}{ democracy } & $0.631 *$ & -0.172 & -0.0594 & -0.108 & 0.0445 & -0.0555 \\
\hline & $(1.88)$ & $(-0.30)$ & $(-0.11)$ & $(-0.20)$ & $(0.058)$ & $(-0.096)$ \\
\hline time effects & yes & yes & yes & yes & yes & yes \\
\hline R-squared (within) & 0.439 & 0.234 & 0.0779 & 0.0881 & 0.0259 & 0.0246 \\
\hline countries & 138 & 131 & 131 & 131 & 131 & 131 \\
\hline observations & 1,005 & 376 & 376 & 376 & 376 & 376 \\
\hline First stage & & & FE & FE & FE & FE \\
\hline \multirow[t]{2}{*}{ lag predicted trade openness $\Omega_{i t-1}^{F G}$} & & & $0.0640 * * *$ & $0.0917 * * *$ & $0.0578 *$ & $0.0412 * *$ \\
\hline & & & $(3.22)$ & $(4.73)$ & $(1.85)$ & $(2.31)$ \\
\hline Partial R-squared & & & 0.0261 & 0.0212 & 0.0072 & 0.0102 \\
\hline F-test on excl. instrument & & & 10.38 & 22.48 & 3.41 & 5.36 \\
\hline F-test, p-value & & & 0.0016 & 0.0000 & 0.0669 & 0.0222 \\
\hline
\end{tabular}

$\mathrm{t}$-statistics for OLS estimations and z-statistics for 2LSLS estimations reported in parenthesis (standard errors clustered by country)

Asterisks indicate significance levels: $* \mathrm{p}<0.1, * * \mathrm{p}<0.05, * * * \mathrm{p}<0.01$.

Stock and Yogo (2005) $10 \%$ critical value: $16.38 ; 15 \%$ critical value: $8.96 ; 20 \%$ critical value: $6.66 ; 25 \%$ critical value: 5.53 . 
Table 5: Panel regression results for sub-indicators of credit market deregulation

Instrumental variable: Lag predicted trade openness (Felbermayr and Gröschl, 2013).

\begin{tabular}{|c|c|c|c|c|c|c|}
\hline & (1) & $(2)$ & (3) & (4) & $(5)$ & $(6)$ \\
\hline Dependent variable & \multicolumn{2}{|c|}{ bank ownership } & \multicolumn{2}{|c|}{ private sector credit } & \multicolumn{2}{|c|}{ interest rate controls } \\
\hline estimation method & FE & 2SLS & FE & 2SLS & $\mathrm{FE}$ & 2SLS \\
\hline overall globalization & $\begin{array}{c}0.194 * * * \\
(3.47)\end{array}$ & $\begin{array}{l}-0.154 \\
(-0.52)\end{array}$ & $\begin{array}{c}0.127 * * * \\
(2.70)\end{array}$ & $\begin{array}{c}-0.0255 \\
(-0.10)\end{array}$ & $\begin{array}{c}0.0217 \\
(0.76)\end{array}$ & $\begin{array}{c}-0.00316 \\
(-0.053)\end{array}$ \\
\hline $\ln$ (population) & $\begin{array}{l}3.115 \\
(1.39)\end{array}$ & $\begin{array}{l}2.743 \\
(0.95)\end{array}$ & $\begin{array}{c}4.446^{* *} \\
(2.34)\end{array}$ & $\begin{array}{c}4.060 * * \\
(2.05)\end{array}$ & $\begin{array}{l}0.432 \\
(0.23)\end{array}$ & $\begin{array}{l}0.385 \\
(0.20)\end{array}$ \\
\hline democracy & $\begin{array}{l}-0.921 \\
(-0.87) \\
\end{array}$ & $\begin{array}{l}-0.709 \\
(-0.70) \\
\end{array}$ & $\begin{array}{l}-0.265 \\
(-0.33) \\
\end{array}$ & $\begin{array}{c}-0.0963 \\
(-0.11) \\
\end{array}$ & $\begin{array}{l}0.290 \\
(0.63) \\
\end{array}$ & $\begin{array}{l}0.320 \\
(0.72) \\
\end{array}$ \\
\hline time effects & yes & yes & yes & yes & yes & yes \\
\hline R-squared (within) & 0.315 & 0.139 & 0.119 & 0.0690 & 0.0258 & 0.0224 \\
\hline countries & 126 & 126 & 130 & 130 & 131 & 131 \\
\hline observations & 361 & 361 & 379 & 379 & 370 & 370 \\
\hline First stage & & $\mathrm{FE}$ & & $\mathrm{FE}$ & & $\mathrm{FE}$ \\
\hline lag predicted trade openness $\Omega_{i t-1}^{F G}$ & & $\begin{array}{c}0.0603 * * * \\
(3.38) \\
\end{array}$ & & $\begin{array}{c}0.0809 * * \\
(2.53) \\
\end{array}$ & & $\begin{array}{c}0.0706 * * * \\
(2.83) \\
\end{array}$ \\
\hline Partial R-squared & & 0.0237 & & 0.0413 & & 0.0305 \\
\hline F-test on excl. instrument & & 11.42 & & 6.42 & & 8.00 \\
\hline F-test, p-value & & 0.0010 & & 0.0125 & & 0.0054 \\
\hline
\end{tabular}

t-statistics for OLS estimations and z-statistics for 2LSLS estimations reported in parenthesis (standard errors clustered by country)

Asterisks indicate significance levels: $* \mathrm{p}<0.1, * * \mathrm{p}<0.05, * * * \mathrm{p}<0.01$.

Stock and Yogo (2005) 10\% critical value: $16.38 ; 15 \%$ critical value: $8.96 ; 20 \%$ critical value: $6.66 ; 25 \%$ critical value: 5.53 . 
Table A1. Credit Market Regulation Indicators by the Frazer Institute - Economic Freedom of the World (Gwartney et al., 2012).

\begin{tabular}{|c|c|c|}
\hline Indicator & Description & Source \\
\hline $\begin{array}{l}\text { Ownership of } \\
\text { banks }\end{array}$ & $\begin{array}{l}\text { Data on the percentage of bank deposits held in privately owned banks were used to construct rating intervals. Countries } \\
\text { with larger shares of privately held deposits received higher ratings. When privately held deposits totaled between } 95 \% \\
\text { and } 100 \% \text {, countries were given a rating of } 10 \text {. When private deposits constituted between } 75 \% \text { and } 95 \% \text { of the total, a } \\
\text { rating of } 8 \text { was assigned. When private deposits were between } 40 \% \text { and } 75 \% \text { of the total, the rating was } 5 \text {. When private } \\
\text { deposits totaled between } 10 \% \text { and } 40 \% \text {, countries received a rating of } 2 \text {. A zero rating was assigned when private } \\
\text { deposits were } 10 \% \text { or less of the total. }\end{array}$ & $\begin{array}{l}\text { James R. Barth, Gerard Caprio, } \\
\text { Jr., and Ross Levine, Bank } \\
\text { Regulation and Supervision } \\
\text { (various years); James R. Barth, } \\
\text { Gerard Caprio, and Ross Levine, } \\
\text { Rethinking Bank Regulation: Till } \\
\text { Angels Govern (2006). }\end{array}$ \\
\hline $\begin{array}{l}\text { Private sector } \\
\text { credit }\end{array}$ & $\begin{array}{l}\text { This sub-component measures the extent to which government borrowing crowds out private borrowing. If available, } \\
\text { this sub-component is calculated as the government fiscal deficit as a share of gross saving. Since the deficit is expressed } \\
\text { as a negative value, higher numerical values result in higher ratings. The formula used to derive the country ratings for } \\
\text { this sub-component was }\left(-\mathrm{V}_{\max }-\mathrm{V}_{\mathrm{i}}\right) /\left(\mathrm{V}_{\max }+\mathrm{V}_{\min }\right) \text { multiplied by } 10 . \mathrm{V}_{\mathrm{i}} \text { is the deficit to gross investment ratio, and the } \\
\text { values for } \mathrm{V}_{\max } \text { and } \mathrm{V}_{\min } \text { are set at } 0 \text { and }-100.0 \% \text {, respectively. The formula allocates higher ratings as the deficit gets } \\
\text { smaller (i.e., closer to zero) relative to gross saving. If the deficit data are not available, the component is instead based } \\
\text { on the share of private credit to total credit extended in the banking sector. Higher values are indicative of greater } \\
\text { economic freedom. Thus, the formula used to derive the country ratings for this sub-component was }\left(\mathrm{V}_{\mathrm{i}}-\mathrm{V}_{\min }\right) /\left(\mathrm{V}_{\max }-\right. \\
\left.\mathrm{V}_{\min }\right) \text { multiplied by } 10 . \mathrm{V}_{\mathrm{i}} \text { is the share of the country's total domestic credit allocated to the private sector and the values } \\
\text { for } \mathrm{V}_{\max } \text { and } \mathrm{V}_{\min } \text { are set at } 99.9 \% \text { and } 10.0 \% \text {, respectively. The } 1990 \text { data were used to derive the maximum and } \\
\text { minimum values for this component. The formula allocates higher ratings as the share of credit extended to the private } \\
\text { sector increases. }\end{array}$ & $\begin{array}{l}\text { World Bank, World Development } \\
\text { Indicators (various issues); } \\
\text { International } \\
\text { Monetary Fund, International } \\
\text { Financial Statistics (various } \\
\text { issues). }\end{array}$ \\
\hline $\begin{array}{l}\text { Interest rate } \\
\text { controls/ } \\
\text { negative real } \\
\text { interest rates }\end{array}$ & $\begin{array}{l}\text { Data on credit-market controls and regulations were used to construct rating intervals. Countries with interest rates } \\
\text { determined by the market, stable monetary policy, and positive real deposit and lending rates received higher ratings. } \\
\text { When interest rates were determined primarily by market forces and the real rates were positive, countries were given a } \\
\text { rating of } 10 \text {. When interest rates were primarily market determined but the real rates were sometimes slightly negative } \\
\text { (less than } 5 \% \text { ) or the differential between the deposit and lending rates was large ( } 8 \% \text { or more), countries received a } \\
\text { rating of } 8 \text {. When the real deposit or lending rate was persistently negative by a single-digit amount or the differential } \\
\text { between them was regulated by the government, countries were rated at } 6 \text {. When the deposit and lending rates were fixed } \\
\text { by the government and the real rates were often negative by single-digit amounts, countries were assigned a rating of } 4 \text {. } \\
\text { When the real deposit or lending rate was persistently negative by a double-digit amount, countries received a rating of } \\
\text { 2. A zero rating was assigned when the deposit and lending rates were fixed by the government and real rates were } \\
\text { persistently negative by double-digit amounts or hyperinflation had virtually eliminated the credit market. }\end{array}$ & $\begin{array}{l}\text { World Bank, World Development } \\
\text { Indicators (various issues); } \\
\text { International Monetary Fund, } \\
\text { International Financial Statistics } \\
\text { (various issues). }\end{array}$ \\
\hline
\end{tabular}

